\title{
Kalkınma Planlarında Sağlık Eğitimi: Ak Parti İktidarları Dönemi Üzerine İnceleme
}

\author{
Health Education in Development Plans: An Analysis on the Period of Ak Party Power
}

\author{
Ali Serinoğlu* (1) \\ İzmir Bakırçay Üniversitesi, Rektörlük, İzmir, Türkiye
}

Öz

Nüfus yapısındaki değişmeler, bilimdeki ilerlemeler, kişilerin ve küreselleşen toplumların beklentilerindeki artı̧̧ gibi sağlıkta paradigma farklılaşması sebebiyle, sağlık eğitimi her geçen gün daha önemli bir hale gelmiştir. Ülkemizde sağlı eğitimi kapsamında üniversitelerde tıp doktorluğu, diş hekimliğii, eczacılık, fizyoterapistlik, hemşirelik, ebelik, sağlık teknikerliği ve diğer bazı sağlık mesleklerine yönelik hizmet öncesi eğitim programları verilmektedir. Kanunlar ve yönetmeliklerin yanı sıra sağlık eğitimi politikalarına ve uygulamalarına yön veren uluslararası antlaşmalar, hükümet programları ve kalkınma planları gibi bir dizi unsur bulunmaktadır. Bu çalışmada Türkiye'de son iktidar döneminde sağlık eğitimi politikalarını incelemek amaçlanmıştır. Bu amaçla AK Parti iktidarları döneminde hazırlanan Kalkınma Planlarında yer alan sağlık eğitimi politikaları incelenmiştir. Tarama modeli ile yürütülen bu araştırmada veriler doküman analizi yöntemlerinden betimsel analiz tekniği ile analiz edilmiştir. Araştırma sonucunda ulaşılan bazı sonuçlar şunlardır. Dokuzuncu Beş Yıllık Kalkınma Planında çoğunlukla sağlık personeli açığının giderilmesine yönelik olarak eğitim programlarının kontenjanlarının arttırılması gereği üzerinde durulmaktadır. Onuncu Beş Yıllık Kalkınma Planında ise nitelik sorununun üzerine daha çok önem verildiği görülmektedir. Dokuzuncu Beş Yıllık Kalkınma Planında yaşam kalitesinin yükseltilmesine yönelik sağlık araştırmalarının öncelikli alanlar olarak destekleneceği belirtilmiştir. Onuncu Beş Yıllık Kalkınma Planında tamamlayıcı tıbbın önemi vurgulanmış ve tamamlayıcı tıbbın, tıp eğitimine entegrasyonunun sağlanacağı belirtilmiştir.

Anahtar Kelimeler: AK Parti, Sağlık Eğitimi, Kalkınma Planı, Eğitim Politikası.

\begin{abstract}
Health education has become more important day by day because of the paradigm shift in health, such as changes in population structure, improvement at science, and increase in the expectations of people and globalizing societies. Within the health education in our country, preservice training programs are given in universities for medical medicine, dentistry, pharmacy, physiotherapist, nursing, midwifery, health technician and some other health professions. There are a number of elements, such as international agreements, government programs and development plans that guide health education policies and practices, as well as laws and regulations. In this study, it was aimed to examine health education policies in Turkey during the last period of ruling party. For this purpose, the health education policies included in the Development Plans prepared during The Justice and Development Party governments period were examined. In this study conducted with survey model, the data analyzed with the descriptive analysis technique of the document analysis methods. Some of the conclusions reached as a result of the research are as follows. In the Ninth Five-Year Development Plan, it is emphasized that the quotas of education programs should be increased in order to eliminate the health personnel shortage. In the Tenth Five-Year Development Plan, more attention was paid to the issue of quality. It is stated in the Ninth Five-Year Development Plan that health research will be supported as priority areas. In the Tenth Five-Year Development Plan, the importance of complementary medicine was emphasized and it was stated that the integration of complementary medicine into medical education would be provided.
\end{abstract}

Keywords: AK Party, Health Education, Development Plan, Education Policy. 


\section{Giriş}

İnsanın birey ve toplum olarak, bilimsel bilgi sınırlarını genişleterek mevcut kaynak ve imkânlardan en iyi biçimde yararlanıp, bu yolla daha üstün bir hayat düzeyine ulaşma amacıyla çevresini kontrol altına alma çabası kalkınma olarak adlandırılabilir (Gönülaçar, 2014:7). Kamusal veya özel örgütler, önceden belirledikleri amaçlara ulaşmak üzere çeşitli yol, yöntem ve araçlar kullanır ve çok sayıda karar alırlar. En büyük siyasal ve toplumsal örgüt olan devlet, vatandaşına kamusal alanda etkin hizmet sunabilmek için çeşitli yol ve yöntemlerden faydalanmakta ve bunun için politika üretip uygulamaktadır (Demirhan, 2016: 45). 1961 Anayasası ekonomik, sosyal ve kültürel gelişmeyi gerçekleştirme aracı olarak "plan"1 öngörmüş ve bunun uygulanmasını devletin başlıca görevlerinden biri olarak kabul etmiştir. Devlet Planlama Teşkilatı'nın kurulması ile "uzun vadeli plan" olarak anılan daha sonra beş yıllık dönemi kapsayan bu planlamaya "Beş Yıllık Kalkınma Planı" adı verilmiştir. Siyasi iktidarlarca hazırlatılan bu belgeler genellikle, ülke ve toplumun bir önceki dönemdeki ve planın yapıldığı tarihteki ekonomik, sosyal ve kültürel durumu çözümleyerek; hazırlandığı beş yıllık dönem için belirlenen genel ve özel politikaları saptayıp bu politikaların uygulanması için öncelikleri, önlemleri, uygulamaları ve uygulanacak ilke ve yöntemleri belirtmektedir (Karaer, 1991, s. 51).

Dünya Sağlık Örgütü’nün “bireylerin ve toplumların sağlıklarını, bilgilerini arttırma ve tutumlarını etkileme yoluyla, iyileştirmelerine yardımcı olmak üzere tasarlanmış öğrenme deneyimlerinin kombinasyonu" olarak tanımlanan sağlık eğitimi (Health Education, t.y.), bireyin ve toplumun gereksinimlerini karşılayacak, sağlıklı yaşam için kişilerin sağlıklarını korumalarını ve geliştirmelerini, tedavi olanaklarından yararlanmaları ve olumlu bir çevre yaratmalarını sağlayacak davranış değişikliği oluşturmayı amaçlamaktadır (Ulusoy-Gökkoca, 2001, s. 371). Nüfus yapısındaki değişmeler, bilimdeki ilerlemeler, kişilerin ve küreselleşen toplumların beklentilerindeki artış gibi sağlıkta paradigma farklılaşması sebebiyle, sağlık eğitimi her geçen gün daha önemli bir hale gelmiştir (Özsarı, 2013). Dünya genelinde sağlık eğitimi için etkili modellere büyük bir ihtiyaç vardır (Malini, Copnell, Moss, 2017). Yirminci yüzyılın ilk yarılarında kimya, fizik, fizyoloji, mikrobiyoloji ve mühendislik gibi uygulamalı bilimlerin hızla gelişmesinden kaynaklı olarak hastalıkların teşhis ve tedavisinde kullanılan tekniklerin ilerlemesi ile sağlık eğitimi de değişiklikler göstermeye başlamıştır (OrtegaNavas, 2017). Bu değişiklerden ülkelerin sağlık sistemlerinin nasıl etkilendiğine yönelik olarak birçok araştırma yapılmıştır (Chang, et al., 2017; Chung, Cho, 2017; Dornelas, Merlin-Servilha, Pinto-Giannini, Piccolotto-Ferreira, 2017; Malini, Copnell, Moss, 2017; El-Awasi, Anderson, Barr, Wilby, Wilbur, Bainbridge, 2016).

Ülkemizde sağlı eğitimi kapsamında üniversitelerde tıp doktorluğu, diş hekimliği, eczacılık, fizyoterapistlik, hemşirelik, ebelik, sağlık teknikerliği ve diğer bazı sağlık mesleklerine yönelik hizmet öncesi eğitim programları verilmektedir. Yükseköğretim Kurulu ve meslek liseleri tarafından düzenlenen bu eğitimlerde artan nüfus ile birlikte sağlık hizmetlerine olan talep, kronik hastalıklar ve geriatri sağlık hizmetlerine yönelik ihtiyaçlar dikkate alınarak kontenjanlar belirlenmektedir (Solak, 2012-2013: 18). Bunun yanı sıra, Sağlık Bakanlığı Sağlık Hizmetleri Genel Müdürlüğü her yıl bakanlığa bağlı tüm personel için ayrıntılı bir Hizmetiçi Eğitim Planı hazırlayıp uygulanışını sağlayarak ve Sağlık Hizmetleri Genel Müdürlüğü’ne bağlı Eğitim ve Sertifikasyon Hizmetleri Daire Başkanlığı da sağlık alanında düzenlenecek tüm sertifikalı eğitimlere ilişkin düzenlemeleri yaparak aday personelin ve çalışanların eğitimini sağlamaktadır (Sağlık Hizmetleri Genel Müdürlüğü, t.y.).

Ülkemizde sağlık eğitiminin planlanması, düzenlenmesi ve uygulanması ile ilgili başta 1987 tarih ve 3359 sayılı Sağlık Hizmetleri Temel Kanunu olmak üzere, 2011 tarih ve 663 sayılı Sağlık Bakanlığı ve Bağlı Kuruluşlarının Teşkilat ve Görevleri Hakkında Kanun Hükmünde Kararname, 1954 tarih ve 6283 sayılı Hemşirelik Kanunu, 1953 tarih ve 6197 sayılı Eczacılar ve Eczaneler Hakkında Kanun, 2014 tarihli Sağlık Bakanlığı Sertifikalı Eğitim Yönetmeliği, 2014 tarihli Tıpta ve Diş Hekimliğinde Uzmanlık Eğitimi Yönetmeliği gibi yasal metinler yer almaktadır. Kanunlar ve yönetmeliklerin yanı sıra eğitim politikalarına ve 
uygulamalarına yön veren unsurlardan yasal belge niteliği taşıyan yazılı metinler Anayasa, Uluslararası antlaşmalar, Hükümet programları ve Kalkınma Planları'dır (Türkoğlu, 2016). Sağlık dışı sektörlerde alınan kararlar da çoğunlukla toplumun sağlığını etkileyebilirler. Özellikle Avrupa, Avusturalya ve Kanada'da kullanılan Sağlık Etki Değerlendirmesi sistemi sağlık sektörünün dışından kaynaklanan politika, plan veya programların potansiyel sağlık etkilerini incelemek için sistematik bir yöntem sağlamaktadır (Pharr, Gakh, Coughenour, Clark, 2017). Bu çalışmada AK Parti iktidarları döneminde sağlık eğitimi politikalarını incelemek amaçlanmıştır. Bu amaçla Adalet ve Kalkınma Partisi (AK Parti) iktidarları döneminde hazırlanan Kalkınma Planlarında yer alan sağlık eğitimi politikaları incelenmiştir. Ön lisans, lisans, yüksek lisans ve doktora olarak yükseköğretimde yapılanan sağlık eğitimi analiz edilirken genel eğitim içindeki yeri, sağlık harcamaları ve araştırma geliştirme politikaları da göz ardı edilmemiş ve ayrı başlıklar halinde incelenmiştir.

\section{Yöntem}

Bu araştırma tarama modeli ile yürütülmüştür. Tarama modeli Karasar (2012) tarafindan, geçmişte ya da halen var olan bir durumu var olduğu şekliyle betimlemeyi amaçlayan araştırma yaklaşımları olarak tanımlanmıştır. Nesnenin ya da bireyin doğrudan kendisi incelenebildiği tarama araştırmalarında aynı zamanda önceden tutulmuş çeşitli kayıtlara, eski kalıntılara başvurarak, elde edilen dağınık veriler araştırmacının gözlemleri ile bir sistem içinde bütünleştirilerek yorumlanmaktadır. Bu araştırmada araştırma konusu ile ilgili olan yazılı ve basılı belgelerden oluşan tarihsel veri kaynakları geçerlik, ilgililik ve önem açılarından eleştiri süzgecinden geçirilmiştir.

Verilerin analiz aşamasında doküman incelemesi yöntemi kullanılmıştır. Doküman incelemesi, diğer yöntemlerin kullanıldığı durumlara ek bilgi kaynăğ olarak ya da tek başına, araştırılması hedeflenen olgu veya olaylar hakkında bilgi içeren yazılı materyallerin analizi şeklinde bir araştırma yöntemi olabilmektedir (Yıldırım ve Şimşek, 2008, s. 187). Nitel araştırmalarda doküman analizi iki yaklaşımla yapılmaktadır. Bunlar betimsel analiz ya da içerik analizi yaklaşımıdır (Yıldırım ve Şimşek, 2008, s. 223). Bu çalışmada betimsel analiz tekniği kullanılmıştır. Elde edilen bulguları düzenlenmiş ve yorumlanmış bir biçimde okuyucuya sunmayı amaçlayan betimsel analiz tekniğinde edilen veriler, öncelikle sistematik ve açı bir biçimde betimlenir. Daha sonra yapılan bu betimlemeler açıklanır ve yorumlanır, neden-sonuç ilişkileri irdelenir ve sonuçlara ulaşı1ır (Yıldırım ve Şimşek, 2008, s. 224).

\section{Bulgular}

3 Kasım 2002 tarihinde yapılan genel seçim sonucunda 58. Hükümeti kuran Adalet ve Kalkınma Partisi bu tarihten itibaren arka arkaya dört dönem boyunca iktidarda kalmış ve hala görevine devam etmektedir (Hükümet Bilgileri, t.y.). AK Parti'nin hükümete geldiği tarihte 2001-2005 yılları arasını kapsayan Sekizinci Beş Yıllık Kalkınma Planı 57. Hükümet tarafından 27.06.2000 tarihinde kabul edilmiş ve yürürlüğe konulmuştur (TC Kalkınma Bakanlığı, 2000). Bu plan, Bülent Ecevit hükümeti tarafından hazırlanmış olduğu için çalışma kapsamı dışında tutulmuştur. Bununla birlikte 2019-2023 yıllarını kapsayan 11. Kalkınma Planının uygulamaya yansımaları çalışmanın yürütüldüğü tarihte henüz analiz edilemeyeceği için çalışma kapsamı dişında tutulmuştur.

1 Temmuz 2006 tarihinde kabul edilen 2007-2013 yılları arasını kapsayan Dokuzuncu Beş Yıllık Kalkınma Planı, "İstikrar içinde büyüyen, gelirini daha adil paylaşan, küresel ölçekte rekabet gücüne sahip, bilgi toplumuna dönüşen, AB'ye üyelik için uyum sürecini tamamlamış bir Türkiye" vizyonu ve Uzun Vadeli Strateji (2001-2023) çerçevesinde hazırlanmıştır (TC Kalkınma Bakanlığı, t.y.). Planda aşağıda yer alan stratejik amaçlar, gelişme eksenleri olarak belirlenmiştir:

- Rekabet Gücünün Artırılması,

- İstihdamın Artırılmas1, 
- Beşeri Gelişme ve Sosyal Dayanışmanın Güçlendirilmesi,

- Bölgesel Gelişmenin Sağlanması,

- Kamu Hizmetlerinde Kalitenin ve Etkinliğin Artırılması.

2 Temmuz 2013 tarihinde kabul edilen 2014-2018 yılları arasını kapsayan Onuncu Beş Yıllık Kalkınma Planı, ülkemizin 2023 hedefleri doğrultusunda, toplumumuzu yüksek refah seviyesine ulaştırma yolunda, küresel ekonomide geleceğe dönük risklerin ve belirsizliklerin sürdüğü, dünya ekonomisinde değişim ve dönüşümlerin yaşandığ 1 , yeni dengelerin oluştuğu, gelişmiş ve gelişmekte olan ülkeler arasında güç dengelerinin yeniden şekillendiği bir ortamda hazırlanmıştır. Onuncu Kalkınma Planı; yüksek, istikrarlı ve kapsayıcı ekonomik büyümenin yanı sıra hukukun üstünlüğü, bilgi toplumu, uluslararası rekabet gücü, insani gelişmişlik, çevrenin korunması ve kaynakların sürdürülebilir kullanımı gibi unsurları kapsayacak şekilde tasarlanmıştır. Planda, ülkemizin ekonomik ve sosyal kalkınma süreci bütüncül ve çok boyutlu bir bakış açısıyla ele alınmış, insan odaklı kalkınma anlayışı çerçevesinde katılımcı bir yaklaşım benimsenmiştir. 2023 hedeflerine ve Onuncu Kalkınma Planının amaçlarına ulaşılabilmesi açısından öncelikli alanlarda, temel yapısal sorunlara çözüm olabilecek, dönüşüm sürecine katkıda bulunabilecek, kurumlar arası koordinasyon ve sorumluluk gerektiren 25 adet program tasarlanmıştır (TC Kalkınma Bakanlığı, 2013).

AK Parti iktidarları dönemlerinde hazırlanmış olan Dokuzuncu ve Onuncu Kalkınma Planlarında hükümetin "Sağlık Eğitimi" alanındaki politikaları sağlık eğitimi alanını etkilemesi muhtemel genel eğitim politikaları, sağlık harcamaları ve sağlıkta Ar-Ge politikalarını içerecek biçimde aşağıdaki dört alt başlık altında yer almaktadır.

\section{Genel Eğitim Politikaları}

\subsection{Dokuzuncu Beş Yıllık Kalkınma Planı'nda genel eğitim politikaları.}

- Plan döneminde ortaöğretim okullaşma oranlarındaki artışla birlikte yükseköğretime olacak talep artışını karşılamak üzere, yükseköğretim okullaşma oranının yüzde 48'e ulaşması planlanmaktadır (TC Kalkınma Bakanlığı, t.y.: md. 354).

- Toplumsal gelişmenin sağlanması amacıyla; düşünme, algılama ve sorun çözme yeteneği gelişmiş, Atatürk ilkelerine bağl1, demokratik, özgürlükçü, milli ve manevi değerleri özümsemiş, yeni fikirlere açık, kişisel sorumluluk duygusuna sahip, çağdaş uygarlığa katkıda bulunabilen, bilim ve teknoloji kullanımına ve üretimine yatkın, sanata değer veren, beceri düzeyi yüksek, üretken ve yaratıcı, bilgi çağı insanı yetiştirilecektir (TC Kalkınma Bakanlığı, t.y.: md. 582).

- Eğitim sistemi, insan kaynaklarının geliştirilmesini desteklemek üzere, yaşam boyu eğitim yaklaşımıyla ve bütüncül olarak ele alınacak; sistemin etkinliği, erişilebilirliği ve firsat eşitliğine dayalı yapısı güçlendirilecektir (TC Kalkınma Bakanlığı, t.y.: md. 583).

- Ortaöğretim; program türünü esas alan, yatay ve dikey geçişlere imkan veren, etkin bir rehberlik ve yönlendirme hizmetini içeren esnek bir yapıya kavuşturulacaktır. Programlar geniş tabanlı ve modüler esasa göre düzenlenecektir (TC Kalkınma Bakanlığı, t.y.: md. 588).

- Eğitimde kalitenin artırılması amacıyla, yenilikçiliği ve araştırıcılığı esas alan müfredat programları ülke geneline yaygınlaştırılacak, öğrenciler bilimsel araştırmaya ve girişimciliğe teşvik edilecektir (TC Kalkınma Bakanlığı, t.y.: md. 589).

- Her kademedeki eğitim tesislerinin etkin kullanılabilmesi için standartlar ve ortak kullanım imkanları geliştirilecektir. Okulların bilgi ve iletişim teknolojileri altyapısı, eğitim yazılımları öncelikli olmak üzere güçlendirilecek, yenilenen müfredatın gerektirdiği ortamlar ve donanım sağlanacaktır (TC Kalkınma Bakanlığı, t.y.: md. 590). 
- Müfredat programlarındaki ve eğitim yöntemlerindeki değişiklikler dikkate alınarak öğretmen yeterlilikleri sürekli olarak geliştirilecek, gereken yeterliliklerin kazandırılabilmesi için hizmet öncesi ve hizmet içi eğitimde etkin yöntemler uygulanacaktır (TC Kalkınma Bakanlığı, t.y.: md. 591).

- Yeni kurulan üniversiteler başta olmak üzere, öğretim üyesi ihtiyacını karşılamak amacıyla yurtiçi ve yurtdışında öğretim üyesi yetiştirme programlarına devam edilecektir (TC Kalkınma Bakanlığı, t.y.: md. 592).

- Bilgi toplumuna geçiş sürecinde ihtiyaç duyulan insangücünün yetiştirilebilmesi için yabancı dil öğretimi etkinleştirilecek, bilgi ve iletişim teknolojilerinin derslerde kullanılmasını sağlayacak yöntemler geliştirilecek ve yaygınlaştırılacaktır (TC Kalkınma Bakanlığı, t.y.: md. 593).

- Yükseköğretim kurumlarında finansman kaynakları geliştirilecek ve çeşitlendirilecek; öğrenci katkı paylarının, mali gücü olmayan başarılı öğrencilere burs ve kredi sağlanması şartıyla yükseköğretimin finansmanındaki payının artırılmasına yönelik düzenlemeler yapılacaktır (TC Kalkınma Bakanlığı, t.y.: md. 596).

- Eğitime ayrılan özel kaynaklar eğitimde fırsat eşitliğine imkan sağlayacak şekilde yönlendirilecektir. Bütün eğitim kademelerinde özel sektörün payı artırılacak, kamu kaynaklarının en fazla ihtiyaç duyan kesimlere yönlendirilmesi sağlanacaktır. Etkin bir kalite değerlendirme ve denetim sistemi kurulması koşuluyla özel yükseköğretim kurumlarının açılabilmesine imkan sağlanacaktır (TC Kalkınma Bakanlığı, t.y.: md. 597).

- Eğitim sisteminin etkinliğinin artırılması, eğitime ayrılan kaynakların daha verimli kullanılması, öğrenciler ve aileleri üzerindeki mali, sosyal ve psikolojik yüklerin hafifletilmesi amacıyla eğitim sistemi, sınav odaklı yapıdan kurtarılacaktır. Yükseköğretime giriş sistemi; öğrencileri programlar hakkında yeterli düzeyde bilgilendiren, ilgi ve yeteneklerini ortaöğretim boyunca çok yönlü bir süreçle değerlendiren, okul başarısına dayalı ve müfredat programlarıyla daha uyumlu bir yapıya kavuşturulacaktır (TC Kalkınma Bakanlığı, t.y.: md. 598).

- Ortaöğretim ve yükseköğretime hazırlık dershanelerinin özel okullara dönüştürülmesine yönelik teşvikler sağlanacaktır (TC Kalkınma Bakanlı̆̆ı, t.y.: md. 599).

\subsection{Onuncu Beş Yıllık Kalkınma Planı’nda genel eğitim politikaları.}

- Düşünme, algılama ve problem çözme yeteneği gelişmiş, demokratik değerleri ve millî kültürü özümsemiş, paylaşıma ve iletişime açık, sanat ve estetik duyguları güçlü, özgüven ve sorumluluk duygusu ile girişimcilik ve yenilikçilik özelliklerine sahip, bilim ve teknoloji kullanımına ve üretimine yatkın, bilgi toplumunun gerektirdiği temel bilgi ve becerilerle donanmış, üretken ve mutlu bireylerin yetişmesi eğitim sisteminin temel amacıdır (TC Kalkınma Bakanlığı, 2013: md. 142).

- Toplumun ve ekonominin ihtiyaçlarına duyarlı, paydaşlarıyla etkileşim içerisinde olan, ürettiği bilgiyi ürüne, teknolojiye ve hizmete dönüştüren, akademik, idari ve mali açıdan özerk üniversite modeli çerçevesinde küresel ölçekte rekabetçi bir yükseköğretim sistemine ulaşılması hedeflenmektedir (TC Kalkınma Bakanlı̆̆ı, 2013: md. 143).

- Eğitim sisteminde, bireylerin kişilik ve kabiliyetlerini geliştiren, hayat boyu öğrenme yaklaşımı çerçevesinde işgücü piyasasıyla uyumunu güçlendiren, firsat eşitliğine dayalı, kalite odaklı dönüşüm sürdürülecektir (TC Kalkınma Bakanlığı, 2013: md. 144).

- Okul türlerinin azaltıldığı, programlar arası esnek geçişlerin olduğu, öğrencilerin ruhsal ve fiziksel gelişimleri ile becerilerini artırmaya yönelik sportif, sanatsal ve kültürel aktivitelerin daha fazla yer aldığ , bilgi ve iletişim teknolojilerine entegre olmuş bir müfredatın bulunduğu, sınav odaklı olmayan, 
bireysel farklılıkları gözeten bir dönüşüm programı uygulanacaktır (TC Kalkınma Bakanlığı, 2013: md. 145).

- Ortaöğretim ve yükseköğretime geçiş sistemi, öğrencilerin ilgi ve yeteneklerini dikkate alan etkin rehberlik ve yönlendirme hizmetleri desteğiyle, süreç odaklı bir değerlendirme yapısına kavuşturulacaktır (TC Kalkınma Bakanlığı, 2013: md. 150).

- Eğitim sisteminin performansının değerlendirilmesine imkân tanıyacak şekilde öğrenci kazanımlarının izlenebilmesini teminen, sınıf temelli başarı düzeyleri, yeterlilikleri ve standartları belirlenecek, ulusal düzeyde çoklu değerlendirme ve denetleme mekanizması geliştirilecektir (TC Kalkınma Bakanlığı, 2013: md. 151).

- Eğitimde alternatif finansman modelleri geliştirilecek, özel sektörün eğitim kurumu açması, özel kesim ve meslek örgütlerinin mesleki eğitim sürecine idari ve mali yönden aktif katılımı özendirilecektir (TC Kalkınma Bakanlığı, 2013: md. 156).

- Örgün ve yaygın eğitim kurumlarında bilgi ve iletişim teknolojisi altyapısı geliştirilecek, öğrenci ve öğretmenlerin bu teknolojileri kullanma yetkinlikleri artırılacaktır. FATïH Projesi tamamlanacak ve teknolojinin eğitime entegrasyonu konusunda nitel ve nicel göstergeler geliştirilerek etki değerlendirmesi yapılacaktır (TC Kalkınma Bakanlığı, 2013: md. 157).

- Eğitim sistemi ile işgücü piyasası arasındaki uyum; hayat boyu öğrenme perspektifinden hareketle iş yaşamının gerektirdiği beceri ve yetkinliklerin kazandırılması, girişimcilik kültürünün benimsenmesi, mesleki ve teknik eğitimde okul-işletme ilişkisinin orta ve uzun vadeli sektör projeksiyonlarını dikkate alacak biçimde güçlendirilmesi yoluyla artırılacaktır (TC Kalkınma Bakanlığı, 2013: md. 158).

- Ulusal Yeterlilik Çerçevesi oluşturularak eğitim ve öğretim programları ulusal meslek standartlarına göre güncellenecek, önceki öğrenmelerin tanınmasını içeren, öğrenci hareketliliğini destekleyen ulusal ve uluslararası geçerliliğe sahip diploma ve sertifikasyon sistemi geliştirilecektir (TC Kalkınma Bakanlı̆̆1, 2013: md. 159).

- Ortaöğretim ve yükseköğretim düzeyindeki mesleki ve teknik eğitimde, program bütünlügü temin edilecek ve nitelikli işgücünün yetiştirilmesinde uygulamalı eğitime ağırlık verilecektir (TC Kalkınma Bakanlığ 1 2013: md. 160).

- Yükseköğretim sistemi, hesap verebilirlik temelinde özerklik, performans odaklılık, ihtisaslaşma ve çeşitlilik ilkeleri çerçevesinde kalite odaklı rekabetçi bir yapıya dönüştürülecektir (TC Kalkınma Bakanlığ 1 2013: md. 161).

- Yükseköğretim Kurulu, standart belirleme, planlama ve koordinasyondan sorumlu olacak şekilde yeniden yapılandırılacaktır (TC Kalkınma Bakanlığı, 2013: md. 162).

- Yükseköğretimde kalite güvencesi sistemi oluşturulacaktır (TC Kalkınma Bakanlığı, 2013: md. 163).

- Yükseköğretim kurumlarının sanayi ile işbirliği içerisinde teknoloji üretimine önem veren, çıktı odaklı bir yapıya dönüştürülmesi teşvik edilecek ve girişimci faaliyetler ile gelir kaynakları çeşitlendirilecektir (TC Kalkınma Bakanlığı, 2013: md. 164).

- Yükseköğretim kurumları çeşitlendirilecek ve yükseköğretim sistemi uluslararası öğrenciler ve öğretim üyeleri için çekim merkezi haline getirilecektir (TC Kalkınma Bakanlığı, 2013: md. 165). 


\section{Sağlık Eğitimine Özel Politikalar}

\subsection{Dokuzuncu Beş Yıllık Kalkınma Planı’nda sağlık eğitimine özel politikalar.}

- Dokuzuncu Plan döneminde sağllk hizmetlerine erişimin önemli göstergeleri olan yatak ve hekim sayısı ile bunların nüfusa oranlarında iyileşmeler öngörülmektedir. Bununla birlikte, bu dönemde yapılacak kontenjan artışının etkisinin ancak bir sonraki plan döneminde görülebilecek olması nedeniyle, hekim başına nüfus konusundaki iyileşme sınırlı kalacaktır (TC Kalkınma Bakanlığı, t.y.: md. 355).

- Mesleki ve teknik eğitimde modüler ve esnek bir sisteme geçilecek, yükseköğretim ve ortaöğretim düzeyindeki mesleki eğitim, program bütünlügünü esas alan tek bir yapıya dönüştürülecek, mesleki eğitimde, nitelikli işgücünün yetiştirilmesinde önemli yeri olan uygulamalı eğitime ağırlık verilecektir (TC Kalkınma Bakanlığı, t.y.: md. 573).

- Mesleki eğitim sistemi, öğrencilere ekip halinde çalışabilme, karar verebilme ve sorun çözebilme, sorumluluk alabilme gibi işgücü piyasasının gerektirdiği temel becerilere sahip öğrenci yetiştirecektir (TC Kalkınma Bakanlığı, t.y.: md. 574).

- Sağlık personeli açığının giderilmesi için eğitim programlarının kontenjanları artırılacaktır. Sağlık eğitiminin kalitesi, öğrencilerin temel sağlik hizmetlerine yönelik becerilerini artıracak şekilde geliştirilecek, ülke gereksinimlerine ve uluslararası standartlara uygun bir yapıya kavuşturulacaktır. Ayrıca, sağlık çalışanlarının niteliğinin iyileştirilmesi amacıyla hizmet içi eğitimler artırılacaktır (TC Kalkınma Bakanlığı, t.y.: md. 604).

\subsection{Onuncu Beş Yıllık Kalkınma Planı’nda sağlık eğitimine özel politikalar.}

- Sağlikta insan gücü, demografik gelişmeler ile uzun vadede ihtiyaç duyulacak yeni meslekler de dikkate alınarak nicelik ve nitelik olarak geliştirilecektir (TC Kalkınma Bakanlığı, 2013: md. 178).

- Üniversite hastanelerinin eğitim ve araştırma faaliyetleri ile sağlık hizmet sunumundaki rolleri net bir şekilde tanımlanarak hem hastanelerin mali sürdürülebilirliğini temin edecek hem de nitelikli tıp eğitimi ve yenilikçi araştırmaların yapılmasını sağlayacak yapısal reformlar hayata geçirilecektir (TC Kalkınma Bakanlığı, 2013: md. 179).

- Tamamlayıcı tıp kapsamındaki tedavi, bitkisel ürün ve hizmet sunucularıyla ilgili kalite ve güvenliğin sağlanması amacıyla standartlar belirlenecek ve bu alan denetim altına alınacaktır. Tamamlayıcı tıbbın, tıp eğitimine ve sağlık uygulamalarına entegrasyonu sağlanacak, bu alanda yapılacak bilimsel araştırmalar desteklenecektir (TC Kalkınma Bakanlığı, 2013: md. 180).

- Veri ve kanıta dayalı sağlı politikalarını geliştirmek amacıyla uluslararası karşılaştırmalara imkân verecek standart ve kalitede verilerin üretilmesi sağlanacaktır (TC Kalkınma Bakanlığı, 2013: md. 182).

\section{Sağlık Harcamaları Politikaları}

\subsection{Dokuzuncu Beş Yıllık Kalkınma Planı’nda sağlık harcamaları politikaları.}

- Dokuzuncu Kalkınma Planı döneminde; öncelikli sektörler arasında yer alan eğitim ve sağlı sektörlerinin kamu yatırım payı artırılacaktır (TC Kalkınma Bakanlığı, t.y.: md. 340).

- Kamu harcamalarının etkinleştirilmesine yönelik çalışmalarda sosyal güvenlik, tarım, sağlık ve personel alanlarına öncelik verilecektir (TC Kalkınma Bakanlığı, t.y.: md. 366). 


\subsection{Onuncu Beş Yıllık Kalkınma Planı’nda sağlık harcamaları politikaları.}

- Toplam nüfusun ve yaşlı nüfus oranının artması, gelir düzeyinin yükselmesi, sağlık bilincinin gelişmesi, yeni sağlık teknolojileri ve sağlık hizmetlerine talebin artması gibi hususların etkisiyle tüm dünyada sağlık harcamalarının artması beklenmektedir. Artan sağlık harcamalarının sosyal güvenlik sistemi üzerinde yarattı̆̆ baskı, özellikle birçok gelişmiş ülkede yüksek kamu borçları ve zayıf bütçe yapısının gerisindeki temel etken olmaya devam edecektir (TC Kalkınma Bakanlığı, 2013: md. 51).

- Mevcut durumda, genç nüfus yapısına sahip olması nedeniyle Türkiye'nin sağlık harcamalarının millî gelir içindeki oranı gelişmiş ülkelerin gerisindedir. İlerleyen dönemde tüm dünyadaki artış beklentisine paralel olarak, Türkiye'de de sağlık harcamalarının artacağı öngörülmektedir. Demografik firsat penceresi yeterince iyi değerlendirilmediği, emeklilik ve sosyal güvenlik sisteminde şimdiden gerekli tedbirler alınmadığı takdirde, artan sağlık harcamaları, önümüzdeki dönemde sosyal güvenlik sistemi ve kamu maliyesi üzerinde baskı oluşturabilecektir (TC Kalkınma Bakanlığı, 2013: md. 52).

- Uzun dönemde artması beklenen sağlık harcamaları; sağlık teknolojilerinin daha yoğun kullanımı, ilaç ve tıbbi malzeme üretimine odaklanma, sağlık turizmini geliştirme gibi fırsat alanlarını da beraberinde getirecektir. Sağlik hizmeti sunum kalitesinde rekabetçiliği giderek artan ülkemiz, başta Avrupa ve OECD ülkeleri olmak üzere nüfusu giderek yaşlanan ülkelere sağlık hizmeti sunma potansiyeline sahiptir. Sağlık turizmi; döviz gelirleri nedeniyle cari denge, emek yoğun yapısı itibarıyla istihdam, turizmde çeşitliliğin ve katma değerin artırılması yoluyla gelir artışı, sağlık altyapısının güçlendirilmesine bağlı olarak yatırım etkisi yaratabilecek bir alandır (TC Kalkınma Bakanlı̆̆1, 2013: md 53).

\section{Ar-Ge Politikaları}

\subsection{Dokuzuncu Beş Yıllık Kalkınma Planı'nda Ar-Ge politikaları.}

- Araştırmacı insan gücü nitelik ve nicelik yönünden geliştirilecek ve özel sektörde araştırmacı istihdamı teşvik edilecektir. Yurtdışındaki Türk araştırmacıların, öncelikli alanlar başta olmak üzere, yurt içinde istihdam edilmesi için gerekli imkanlar sağlanacaktır. Ayrıca, ihtiyaç duyulan alanlarda yabancı araştırmacıların Türkiye'de istihdam edilmeleri desteklenecektir (TC Kalkınma Bakanlığı, t.y.: md. 478).

- Üniversitelerde desteklenen Ar-Ge faaliyetlerinin ülkenin ekonomik, sosyal ve kültürel gelişimine katkı verecek şekilde tasarımlanması sağlanacaktır (TC Kalkınma Bakanlığı, t.y.: md. 480).

- Geleceğe yönelik olarak nanoteknoloji, biyoteknoloji, yeni nesil nükleer teknolojiler ile hidrojen ve yakıt pili teknolojileri; sanayi politikasının öncelik vereceği sektörlerdeki araştırmalar; yerli kaynakların katma değere dönüştürülmesini amaçlayan Ar-Ge faaliyetleri; aşı ve anti-serum başta olmak üzere yaşam kalitesinin yükseltilmesine yönelik sağlı araştırmaları; bilgi ve iletişim teknolojileri ile savunma ve uzay teknolojileri öncelikli alanlar olarak desteklenecektir (TC Kalkınma Bakanlığı, t.y.: md. 482).

\subsection{Onuncu Beş Yıllık Kalkınma Planı’nda Ar-Ge politikaları.}

- Önümüzdeki dönemde teknolojik gelişmelerin belirli alanlarda yoğunlaşarak ekonomik, sosyal ve askeri gelişmeleri şekillendirmesi beklenmektedir. Bu sektörlerin başında bilgi teknolojileri, otomasyon ve ileri üretim teknikleri ve sağlık teknolojileri gelmektedir. Özellikle dijital iletişim, nanoteknoloji, yüzey teknolojileri, malzeme bilimleri, ölçümleme cihazları, biyoteknoloji ve çevre teknolojileri hızlı gelişen alanlar olarak öne çıkmaktadır. Nanoteknoloji ve biyoteknoloji alanlarındaki 
gelişmeler, yeni imkânlar sunmakla birlikte, çevre ve etik boyutlarıyla da gündemde olacaktır (TC Kalkınma Bakanlığı, 2013: md. 30).

- Dünya genelinde nitelikli işgücüne olan talebin artması ve işgücünün daha serbest hareket edebilmesi ülkemiz için çeşitli firsatlar sunmaktadır. İhtiyaç duyulan alanlarda başta bölge ülkelerinden olmak üzere ülkemize beyin göçünün teşvik edilmesi, nitelikli insan gücü kaynă̆ımızı artırarak büyüme potansiyelimize olumlu katkı sağlayacaktır. Diğer taraftan ülkemizin eğitim ve sağlık alanlarında çekim merkezi haline gelmesi uluslararası hareketlilikten azami ölçüde faydalanmasına imkân verebilecektir (TC Kalkınma Bakanlığı, 2013: md. 47).

- Üniversite ve özel sektör işbirliğini daha kolaylaştırıcı ve teşvik edici önlemler alınacak ve ara yüzler oluşturulacaktır. $\mathrm{Bu}$ çerçevede yükseköğretimin yeniden yapılandırılmasında, akademisyenlerin ve öğrencilerin Ar-Ge ve girişimcilik faaliyetlerinin teşvik edilmesine özen gösterilecektir (TC Kalkınma Bakanlığ1, 2013: md. 634).

- Araştırmacı insan gücünün sayısı ve niteliği daha da artırılacak, özel sektörde araştırmacı istihdamı teşvikine devam edilecektir (TC Kalkınma Bakanlığı, 2013: md 635).

- Temel ve sosyal bilimlerde yetkin araştırmacıların yetiştirilmesi desteklenecek, üniversiteler ve kamu kurumları bünyesinde bu alanlardaki araştırmaların sayısı, niteliği ve etkinliği artırılacaktır (TC Kalkınma Bakanlığı, 2013: md. 636).

\section{Tartışma ve Sonuç}

Ülkemizde sağlık eğitiminin planlanmas1, düzenlenmesi ve uygulamalarına yön veren bir dizi unsur bulunmaktadır. Bunlardan biri de Kalkınma Planlarıdır. Bu çalışmada Türkiye'de son iktidar döneminde sağlık eğitimi politikalarını incelemek amaçlanmıştır. Bu amaçla AK Parti iktidarları döneminde hazırlanan Beş Yıllık Kalkınma Planlarında yer alan sağlık eğitimi politikaları incelenmiştir. Tarama modeli ile yürütülen bu araştırmada veriler doküman analizi yöntemlerinden betimsel analiz tekniği ile analiz edilmiştir.

Araştırmada ulaşılan sonuçlardan biri, incelenen Kalkınma Planlarında özel olarak sağlık eğitimi politikalarına çok fazla yer verilmediğidir. Eğitimde kalitenin artırılması, eğitim tesislerinin etkin kullanılabilmesi, öğretim üyesi ihtiyacı, müfredat programlarındaki değişiklikler gibi sağlık eğitimini etkilemesi muhtemel bazı ilkeler genel eğitim politikaları kapsamında verilmiştir. Bunun yanı sıra planlarda, araştırma geliştirmeye yönelik politikaların sağlık eğitimi sürecine aktarılması ve genel bütçe içinde sağlığa ayrılan payın sağlık eğitimi için nasıl kullanılacağı noktalarında bilgiler içermektedir. Her ne kadar kalkınma planları iktisat politikalarının yapımı ve uygulanmasına düzen getirme amacı ile başlatılmış (Özdemir, 2014) geleneksel anlayışa göre kişinin ve hanenin gelirini arttırmayı amaçlamış olsa da (Akgiş, 2015) Dokuzuncu ve Onuncu Beş Yıllık Kalkınma Planlarının istikrarlı ve kapsayıcı ekonomik büyümenin yanı sıra ülkemizin sosyal kalkınma süreci de çok boyutlu bir bakış açısıyla ele alınmıştır (TC Kalkınma Bakanlığı, 2000; TC Kalkınma Bakanlığı, 2013). Bu sebeplerden ötürü planlarda özel olarak sağlık eğitimi politikaları ile ilgili sınırlı bilgi verilmiş gibi görünse de aslında ekonomi odaklı hazırlanmış diğer planlara göre Dokuzuncu ve Onuncu Beş Yıllık Kalkınma Planlarında bu konunun aslında çok yönlü olarak ele alındığını görmekteyiz.

Kalkınma Planlarının farklı hükümetlerce hazırlanmış olması ve hükümetlerin kendi amaç ve eğilimleri için diledikleri gibi kullanabilme zayıflığından kaynaklanan yaklaşım yanlışlığı ve öngörülerin sınırlı ölçüde gerçekleşebilmesi durumu (Karaer, 1991, s. 64) planlarda incelenmiş ve politikaların uygulamadaki yansımaları araştırılmıştır.

İncelenen Kalkınma Planlarında basamaklı bir ilerlemenin yaşandığı anlaşılmaktadır. Örneğin, Dokuzuncu Beş Yıllık Kalkınma Planında çoğunlukla sağlık personeli açığının giderilmesine yönelik olarak eğitim programlarının kontenjanlarının arttırılması gereği üzerinde durulmaktadır. Üniversitelerde halihazırda eğitimöğretim sürecine devam eden programlarda kontenjan arttırılmasının yanı sıra AK Parti hükümeti döneminde 
özel olarak sağlık personeli yetiştirme amacıyla kurulan Sağlık Bilimleri Üniversitesi (Sağlık Bilimleri Üniversitesi, t.y.; Bektemür, Taşçı, Adaş, 2016) bu ilkenin uygulamadaki yansımasının en önemli kanıtı olarak ortaya çıkmaktadır. Sağlık personelinin nicelik olarak istenilen düzeye yakın bir duruma gelmesi öngörüsünün ardından Onuncu Beş Yıllık Kalkınma Planında nitelik sorununun üzerine daha çok önem verildiği görülmektedir. Örneğin planda geçen nitelikli sağlık eğitimi ve yenilikçi araştırmaların yapılmasını sağlayacak yapısal reformların hayata geçirilmesi politikasının uygulamadaki yansımalarından biri üniversitelerde gittikçe yaygınlaşan Merkezi Araştırma Laboratuvarları (Türkoğlu, Kurt, Tabay, 2016), Genetik ve Biyoteknoloji Araştırma ve Uygulama Merkezleri, Farmasötik Bilimler Araştırma Merkezleri, Nanoteknoloji Araştırma Merkezleri (Özer, Şahin, Alpaslan, Parmaksız, 2010) olarak karşımıza çıkmaktadır.

Onuncu Beş Yıllık Kalkınma Planında tamamlayıcı tıbbın önemi vurgulanmış ve tamamlayıcı tıbbın, tıp eğitimine entegrasyonunun sağlanacağı belirtilmiştir. Bu kapsamda 27 Ekim 2014 tarih ve 29158 sayıl1 Geleneksel ve Tamamlayıcı Tıp Uygulamaları Yönetmeliği Resmi Gazetede yayınlanmış ve Sağlık Bakanlığı'na bağlı Sağlık Hizmetleri Genel Müdürlügü̈'nde Geleneksel ve Tamamlayıcı Tıp Daire Başkanlığı kurulmuştur (Geleneksel ve Tamamlayıcı Tıp Uygulamaları Daire Başkanlığı, t.y.).

Dokuzuncu Beş Yıllık Kalkınma Planında yaşam kalitesinin yükseltilmesine yönelik sağlık araştırmalarının öncelikli alanlar olarak destekleneceği belirtilmiştir. Bu ilkenin uygulamadaki yansımalarını bilim ve teknoloji alanlarında kamu ve özel kuruluşların projelerine destek veren TÜBİTAK'ın desteklediği araştırmalara bakarak görebilmekteyiz. 2017 yılı için 1511- Öncelikli Alanlar Ar-Ge Destek Programı kapsamında çağrı açan TÜBİTAK bu alanlardan birini de hekim yetiştirme pratiği açısından hastaya zarar verme riskini en aza indirme amacıyla sağlık eğitiminde simülatörlerin kullanılabilmesi için "Kişiye Özel Cerrahi Planlama ve Eğitim Destek Simülatörlerinin Geliştirilmesi” konusu olarak belirlemiştir (Kişiye Özel Cerrahi Planlama ve Eğitim Destek Simülatörlerinin Geliştirilmesi, t.y.).

AK Parti iktidarları dönemi Kalkınma Planları sağlık eğitimi politikaları açısından genel olarak incelendiğinde, parti iktidarının başarı göstergelerinden biri olan Sağlık Bakanlığı'nın 1 Temmuz 2003 tarihinde başlatmış olduğu Sağlıkta Dönüşüm Programı'nın (Sağlıkta Dönüşüm Programı, t.y.) bir yansıması olarak karşımıza çıkmaktadır. Programa verilen önem doğrultusunda Kalkınma Planlarında da sağlık eğitimine önem verildiği görülmektedir.

Onuncu Kalkınma Planı'nın 52'inci maddesine göre tüm dünyadaki artış beklentisine paralel olarak, ilerleyen dönemlerde Türkiye'de de sağlık harcamalarının artacağı belirtilmektedir. Demografik firsat penceresi yeterince iyi değerlendirilmediği, emeklilik ve sosyal güvenlik sisteminde gerekli tedbirler alınmadığı takdirde, artan sağlık harcamalarının sosyal güvenlik sistemi ve kamu maliyesi üzerinde baskı oluşturabileceği ifadeleri yer almaktadır. Günümüzde sağlık yardımları Sosyal Güvenlik Kurumunca karşılanan kişilerin, sağlıklı kalmalarını, hastalanmaları halinde sağlıklarını kazanmalarını, iş kazası ile meslek hastalığı, hastalık ve analık sonucu tıbben gerekli görülen sağlık hizmetlerinin karşılanmasını, iş göremezlik hallerinin ortadan kaldırılmasını veya azaltılmasını temin etmek amacıyla Kurumca finansmanı sağlanan sağlık hizmetleri, yol, gündelik ve refakatçi giderlerinden yararlanma esas ve usulleri ile bu hizmetlere ilişkin Sağlık Hizmetleri Fiyatlandırma Komisyonunca belirlenen Kurumca ödenecek bedeller 24/3/2013 tarihli ve 28597 sayılı Resmî Gazete'de yayımlanan "Sosyal Güvenlik Kurumu Sağlık Uygulama Tebliği” [SUT] ile belirlenmiştir (Sosyal Güvenlik Kurumu Sağlık Uygulama Tebliği, 2013). Sağlık kuruluşlarında uygulanan hizmet türlerinin dağılımı, işlem hacmi ve işlem maliyeti göz önünde bulundurulduğunda, üniversite hastanelerinin görevinin diğer sağlık kuruluşlarından farklı olması; özellikle hastalar üzerinde teorik eğitimin de verilmesi ile genellikle 1. ve 2. basamak sağlık kuruluşlarında tedavi edilemeyen veya diğer hastanelere nispeten ağır ve uzun tedavileri yapan sağlık hizmetleri sunmasından kaynaklı olarak müracaat eden hasta sayısı, yatan hasta sayısı, yatak doluluk oranı gibi değerler diğer sağlık kuruluşlarına göre daha fazladır (Gülşen ve Yıldıran, 2017). Toplum sağlı̆̆ını ilgilendiren konuların yanı sıra görev ve sorumlulukları kapsamında araştırma ve geliştirme ve tıp eğitiminin yer aldığı üniversite hastanelerine özellikle finansal açıdan koruma sağlanması 
gerekmektedir. Üniversite hastanelerinden beklenen önemli misyonlarda biri, mümkün olan en iyi sağllk hizmet sunucusunu yetiştirme kabiliyeti yani eğitim; bir diğeri ise tüm topluma tıbbi araştırma faydasını sağlamak ve çok geniş bir alana yayılan sağlık sorunları için teşhis ve tedavi yöntemlerinde iyileştirmeler üretmeleridir (Uğurluoğlu, 2015). Bu misyonları nedeniyle üniversite hastanelerinin öğretimsel, teknolojik ve operasyonel anlamda altyapıya sahip olma zorunluluğu olmakta, bu durum ise bütçelerine ek maliyetler oluşturmaktadır. Ancak SUT uygulaması ile birlikte kurumlar, fiyat kısıtlaması üstünde harcama yapmak istemeyerek sağlık sisteminin kalitesinde bir azalmaya yol açabilecektir. 05/07/2018 tarihli ve 28597 say1l Resmi Gazete'de yayımlanan tebliğ ile birlikte sunulan tüm sağlık hizmetlerinin fiyat güncellemeleri, yeni ilaç ve tedavilerin geri ödeme kapsamına alınması, yeşil kartlı hastaların sevk durumları, vazife ve harp malullerine verilen fizik tedavi ve rehabilitasyon uygulamalarındaki tedavi sayı sınırı, ev hemodiyaliz tedavisi için gerekli şartlar gibi birçok konuda SUT'ta revizyona gidilmiştir (Sosyal Güvenlik Kurumu Sağlık Uygulama Tebliğinde Değişiklik Yapılmasına Dair Tebliğ, 2018). Ancak üniversite hastanelerinin sağlık eğitimi yönü dikkate alındığında maliyet-gelir dengesizliğinin önüne geçebilecek eğitim faaliyetleri, araştırma ve geliştirmeye yönelik hizmet, sarf ve teknolojik malzemelerin ödemeleriyle ilgili herhangi bir değişikliğin yayımlanan tebliğde yer almadığı görülmektedir. SUT fiyatlandırmasında özellikle eğitim-öğretim faaliyetlerini de yürütmekle sorumlu üniversite hastanelerinin ayrıntılı olarak incelenmesi ve gerekli düzenlemelerin yapılması veya kurumların görev ve sorumluluklarını dikkate alacak, sağlık eğitimini aksatmayacak düzenlemeleri de içeren yeni bir sistemin oluşturulması için Sağlık Bakanlığı, Yükseköğretim Kurulu Başkanlığı, üniversite yönetimleri ve diğer ilgili kurumların yer alacağı çalıştaylar düzenlenip sağlık eğitimindeki bu hususa değinmeleri önerilmektedir.

Dünya genelinde son yıllarda sağlık eğitiminin etkililiğini arttırmak amacıyla eğitim politikalarının sağlık üzerine etkilerini, sağlık eğitiminde hizmetiçi ve disiplinlerarası eğitim, yetkinlik temelli sağlık eğitimi müfredatları, web tabanlı sağlık eğitimi programları, sağlık eğitiminde elektronik sağlık kayıt sistemleri, sağlık eğitiminde yeni teknolojilerin kullanımı gibi neler yapılabileceğine dair birçok konu araştırmacıların ilgisini çekmiştir (Chang, et al., 2017; Chung, Cho, 2017; Morin-Fraile, et al, 2017; Ortega-Navas, 2017; Pharr, Gakh, Coughenour, Clark, 2017; Riley, Riley, 2017; Alla, et al., 2016; Liaw, et al., 2016). Bu çalışmada ulaşılan sonuçlar da Kalkınma Planları doğrultusunda sağlık eğitiminde ulaşılmak istenilen noktaya gelebilmek için öncelikli olarak neler yapılması gerektiğine dair uygulayıcılara yol gösterici nitelik taşımaktadır.

\section{Kaynakça}

Akgiş, Ö. (2015). Bir refah göstergesi olarak Türkiye'de mutluluğun mekânsal dağıllışı. Türk Coğrafya Dergisi, 65, 69-76.

Alla, E-A., Anderson, E., Barr, H., Wilby, K., Wilbur, K., \& Bainbridge, L. (2016). Important steps for introducing interprofessional education into health professional education. Journal of Taibah University Medical Sciences, 11(6), 546-551.

Bektemür, G., Taşçı, A. İ. ve Adaş, G. (2016). The Health Sciences University as a different macro organizational model in education. JAREM, 6, 203-209.

Chang, K. S., Tsai, W. H., Tsai, C. H., Yeh, H. I., Chiu, P. H., Chang, Y. W., .., Lee, S. C. (2017). Effects of health education programs for the elders in community care centers - Evaluated by health promotion behaviors. International Journal of Gerontology, http://dx.doi.org/10.1016/j.ijge.2017. 03.009

Chung, J., \& Cho, I. (2017). The need for academic electronic health record systems in nurse education. Nurse Education Today, 54, $83-88$.

Demirhan, Y. (2016). Kamu politikaları: kavramsal ve kuramsal bir çeç̧eve. S. Aslan ve Y. Demirhan (Ed.), Türk siyasal hayatında Ak Parti Dönemi: Kamu yönetiminde değişim, kamu politikaları, kurumsal ilişkiler (ss.45-70). Bursa: Ekin Basım Yayın Dağıtım.

Dornelas, R., Merlin-Servilha, E. A., Pinto-Giannini, S. P., \& Piccolotto-Ferreira, L. (2017). Voice campaigns in Brazil: effective practices in health education. Journal of Voice, 31(1), 116.e7-116.e12.

Eczacılar ve Eczaneler Hakkında Kanun (t.y.). http://www.mevzuat.gov.tr/Metin1.Aspx?MevzuatKod=1.3.6197\&MevzuatIliski= $0 \&$ sourceXmlSearch $=\&$ Tur=1\&Tertip $=3 \& \mathrm{No}=6197$ adresinden 13.01.2018 tarihinde edinilmiştir. 
El-Awasi, A., Anderson, E., Barr, H., Wilby, K. J., Wilbur, K., \& Bainbridge, L. (2016). Important steps for introducing interprofessional education into health professional education. Journal of Taibah University Medical Sciences, 11(6), 546-551.

Geleneksel ve Tamamlayıcı Tıp Uygulamaları Daire Başkanlığı (t.y.). http://www.getatportal.saglik.gov.tr/ adresinden 13.01.2018 tarihinde edinilmiştir.

Geleneksel ve Tamamlayıcı Tıp Uygulamaları Yönetmeliği (t.y.). http://www.mevzuat.gov.tr/Metin.Aspx?MevzuatKod= 7.5.20164\&MevzuatIliski=0\&sourceXmlSearch=geleneksel\%20ve\%20tamamlay\%C4\%B1c\%C4\%B1 adresinden 13.01 .2018 tarihinde edinilmiştir.

Gönülaçar, Ş. (2014). Kalkınma planları ve eğitim. http://www.academia.edu/8310870/Kalk\%C4\%B1nma_Planlar\% C4\%B1_ve_E\%C4\%9Fitim adresinden 12.01.2018 tarihinde edinilmiştir.

Gülşen, M. A., ve Yıldıran, M. (2017). Mali regülasyon olarak sağlık regülasyonlarının sağlık kurumlarına etkisi: Türkiye'de üniversite hastaneleri ve sağlık uygulama tebliği. Ekonomik ve Sosyal Araştırmalar Dergisi, 13(3), 23-44.

Health Education (t.y.). http://www.who.int/topics/health_education/en/ adresinden 13.01.2018 tarihinde edinilmiştir.

Hemşirelik Kanunu (t.y.). http://www.mevzuat.gov.tr/Metin1.Aspx?MevzuatKod=1.3.6283\&MevzuatIliski= $0 \&$ sourceXmlSearch $=\&$ Tur=1\&Tertip=3\&No=6283 adresinden 13.01.2018 tarihinde edinilmiştir.

Hükümet Bilgileri (t.y.). https://www.tbmm.gov.tr/kutuphane/ e_kaynaklar_kutuphane_hukumetler.html adresinden 13.01 .2018 tarihinde edinilmiştir.

Karaer, T. (1991). Kalkınma Planları ve idari reform. Amme İdaresi Dergisi, 24(2), 43-65.

Karasar, N. (2012). Bilimsel araştırma yöntemleri. Ankara: Nobel Yayınevi.

Kişiye Özel Cerrahi Planlama ve Eğitim Destek Simülatörlerinin Geliştirilmesi: https://www.tubitak.gov.tr/ sites/default/files/292/1511-sab-bmed-2016-2.pdf adresinden 13.01.2018 tarihinde edinilmiştir.

Liaw, S.Y., Ping-Lim, E.Y., Wong, L.F., Yin-Ho, J.T., Mordiffi, S.T., Leng-Ang, A.B., .., Kim-Ang, E.M. (2016). The effect of a web-based educational program on nursing practice in recognising and responding to deteriorating ward patients: A qualitative evaluation study. Collegian, http://dx.doi.org/10.1016/j.colegn.2016.09.008

Malini, H., Copnell, B., \& Moss, C. (2017). Considerations in adopting a culturally relevant diabetes health education programme: An Indonesian example. Collegian, 24(2), 183-190.

Morin-Fraile, V., Sancho-Agredano, R., Galimany-Masclans, J., Guix-Comellas, E.M., Estrada-Masllorens, J.M., Vázquez-Archilla, M., ..., Escofet-Roig, A. (2017). Service learning and health education: Innovation in nursing education. Procedia - Social and Behavioral Sciences, 237, $956-961$.

Ortega-Navas, M.C. (2017). The use of new technologies as a tool for the promotion of health education. Procedia - Social and Behavioral Sciences 237, 23-29.

Özdemir, V. (2014). Türkiye'de planlı kalkınma deneyimleri. Marmara Üniversitesi, https://dumludag.files.wordpress.com /2013/09/ozdemir_planlama.pdf adresinden 05.01.2018 tarihinde erişilmiştir.

Özer, Ö. K., Şahin, L., Alpaslan, M., ve Parmaksız, H. (2010). Üniversite ve kamu kurumları araştırma merkezleri. Ankara: Korza Yayıncilik.

Özsarı, S. H. (2013). Sağlık yönetimi ve sağlık eğitimi ilişkisi. Yükseköğretim Dergisi, 3(1), 9-11.

Pharr, J., Gakh, M., Coughenour, C., \& Clark, S. (2017). Health impact assessment as an instrument to examine the health implications of education policies. Public Health, 145, 83-92.

Riley, B. A., \& Riley, G. (2017). Innovation in graduate medical education - Using a competency based medical education curriculum. International Journal of Osteopathic Medicine, 23, 36-41.

Sağlık Bakanlığı 2017 Yılı Hizmet İçi Eğitim Planı (t.y.). http://www.eshdb.saglik.gov.tr/ Eklenti/8623,2017-hie-plani-41-maddedegistipdf.pdf?0 adresinden 13.01.2018 tarihinde edinilmiştir.

Sağlık Bakanlığı Sertifikalı Eğitim Yönetmeliği (t.y.). http://www.mevzuat.gov.tr/Metin.Aspx?MevzuatKod= 7.5.19376\&MevzuatIliski=0\&sourceXmlSearch=SERT\%C4\%B0F\%C4\%B0KALI adresinden 13.01.2018 tarihinde edinilmiştir.

Sağlık Bakanlığı ve Bağlı Kuruluşlarının Teşkilat ve Görevleri Hakkında Kanun Hükmünde Kararname (t.y.). http://www.mevzuat.gov.tr/Metin1.Aspx?MevzuatKod=4.5.663\&MevzuatIliski=0\&sourceXmlSearch=\&Tur=4\&Tertip=5\&No=663 adresinden 13.01.2018 tarihinde edinilmiştir.

Sağlık Bilimleri Üniversitesi (t.y.). http://www.sbu.edu.tr/ Universitemiz/Tarihcemiz adresinden 13.01.2018 tarihinde edinilmiştir. 
Sağlık Hizmetleri Genel Müdürlüğü (t.y.). www.shgm.saglik.gov.tr adresinden 13.01.2018 tarihinde edinilmiştir.

Sağlık Hizmetleri Genel Müdürlüğü Eğitim ve Sertifikasyon Hizmetleri Daire Başkanlığı Görevleri (t.y.). http://www.eshdb.saglik.gov.tr/TR,5088/daire-baskanliginin-gorevleri.html adresinden 13.01.2018 tarihinde edinilmiştir.

Sağlık Hizmetleri Temel Kanunu (t.y.). http://www.mevzuat.gov.tr/Metin1.Aspx?MevzuatKod= 1.5.3359\&MevzuatIliski=0\&sourceXmlSearch $=\&$ Tur $=1 \&$ Tertip $=5 \& N o=3359$ adresinden 13.01 .2018 tarihinde edinilmiştir.

Sağl1kta Dönüșüm Programı (t.y.). http://www.saglik.gov.tr/TR,11415/saglikta-donusumprogrami.html adresinden 13.01 .2018 tarihinde edinilmiştir.

Solak, M. (2012-2013). Yükseköğretimde sağlık eğitimine genel bir bakış. Sağllk Düşüncesi ve Tıp Kültürü Dergisi, 25, 18-19.

Sosyal Güvenlik Kurumu Sağlik Uygulama Tebliği (2013). http://www.resmigazete.gov.tr/main.aspx?home= http://www.resmigazete.gov.tr/eskiler/2013/03/20130324.htm\&main=http://www.resmigazete.gov.tr/eskiler/2013/03/20130324.htm adresinden 18.01.2018 tarihinde erişilmiştir.

Sosyal Güvenlik Kurumu Sağlık Uygulama Tebliğinde Değişiklik Yapılmasına Dair Tebliğ (2018). http://www.resmigazete.gov.tr/eskiler/2018/07/20180705M1-1.htm adresinden 20.09.2018 tarihinde erişilmiştir.

TC Kalkınma Bakanlığı. (t.y.). Dokuzuncu beş yıllık kalkınma planı. http://www.kalkinma.gov.tr/Pages/content.aspx?List=8661bcf79da5-4ecb-a190-fd4aadbacc02\&ID=1\&Content TypeId=0x0100B6043AD55C311E41A48571E65B9E1AD1 adresinden 13.01.2018 tarihinde edinilmiştir.

TC Kalkınma Bakanlığı. (2000). Sekizinci beş yıllık kalkınma planı. http://www.kalkinma.gov.tr/Pages/content.aspx?List=8661bcf79da5-4ecb-a190-fd4aadbacc02\&ID=2\&Content TypeId=0x0100B6043AD55C311E41A48571E65B9E1AD1 adresinden 13.01.2018 tarihinde edinilmiştir.

TC Kalkınma Bakanlığı. (2013). Onuncu beş yıllık kalkınma planı. http://www.kalkinma.gov.tr/Pages/content.aspx?List=8661bcf79da5-4ecb-a190-fd4aadbacc02\&ID=12\&Source=http\%3A\%2F\%2Fwww\%2Ekalkinma\%2Egov\%2Etr\%2FPages\%2FKalkinma Planlari\%2Easpx\&ContentTypeId=0x0100B6043AD55C311E41A48571E65B9E1AD1 adresinden 13.01.2018 tarihinde edinilmiştir.

Tıpta ve Diş Hekimliğinde Uzmanlık Eğitimi Yönetmeliği (t.y.). http://www.mevzuat.gov.tr/Metin.Aspx?MevzuatKod= 7.5.19629\&MevzuatIliski $=0 \&$ sourceXmlSearch $=\mathrm{t} \% \mathrm{C} 4 \% \mathrm{~B} 1 \mathrm{pta} \% 20 \mathrm{ve} \% 20 \mathrm{di} \% \mathrm{C} 5 \% 9 \mathrm{~F}$ adresinden 13.01 .2018 tarihinde edinilmiştir.

Türkoğlu, D. (2016). Türkiye’de eğitim sisteminin yönetsel yapısı ve eğitim yöneticisi yetiştirme sürecinin tarihsel gelişimi. Yayımlanmamış Doktora Tezi. İnönü Üniversitesi, Eğitim Bilimleri Enstitüsü, Malatya.

Türkoğlu, E. A., Kurt, M., ve Tabay, D. (2016). Profile of central research and application laboratory of Ağrı İbrahim Çeçen University. AIP Conference Proceedings 1726, 020097, doi: 10.1063/1.4945923.

Uğurluoğlu, Ö. (2015). Üniversite hastanelerinde uygulanan organizasyon yapılarının değerlendirilmesi. İsletme Bilimi Dergisi, 3(1), $52-63$.

Ulusoy-Gökkoca, Z. (2001). Sağlık eğitimi açısından temel ilkeler. Sürekli Tip Eğitimi Dergisi (STED), 10(10), 371-374.

Yıldırım, Ş., ve Şimşek, H. (2008). Sosyal bilimlerde nitel araştırma yöntemleri. Ankara: Seçkin Yayıncılık. 